\title{
To Share or Not To Share: Does Local Participation Matter for Spillovers from Foreign Direct Investment?
}

\author{
Beata Smarzynska JAVORCIK \\ and \\ Mariana SPATAREANU*
}

\begin{abstract}
This study examines whether the degree of spillovers from foreign direct investment is affected by the foreign ownership share in investment projects. The analysis, based on an unbalanced panel of Romanian firms during 1998-2000, produces evidence consistent with positive intra-sectoral spillovers resulting from fully-owned foreign affiliates but not from projects with joint domestic and foreign ownership. This finding is in line with the literature suggesting that foreign investors tend to put more resources into technology transfer to their wholly-owned projects than to those owned partially. Further, the data indicate that the presence of partially foreign-owned projects is correlated with higher productivity of domestic firms in upstream industries suggesting that domestic suppliers benefit from contacts with multinational customers. The opposite is true, however, in the case of fully-owned foreign affiliates which appear to have a negative effect on domestic firms in upstream industries. These results are consistent with the observation that foreign investors entering a host country through greenfield projects are less likely to source locally than those engaged in joint ventures or partial acquisitions. They are also in line with the evidence suggesting that fully-owned foreign subsidiaries use newer or more sophisticated technologies than jointly owned investment projects and thus may have higher requirements vis-à-vis suppliers.
\end{abstract}

Keywords: spillovers, foreign direct investment, joint venture, technology transfer

JEL classification: F23

World Bank Policy Research Working Paper 3118, August 2003

The Policy Research Working Paper Series disseminates the findings of work in progress to encourage the exchange of ideas about development issues. An objective of the series is to get the findings out quickly, even if the presentations are less than fully polished. The papers carry the names of the authors and should be cited accordingly. The findings, interpretations, and conclusions expressed in this paper are entirely those of the authors. They do not necessarily represent the view of the World Bank, its Executive Directors, or the countries they represent. Policy Research Working Papers are available online at http:/lecon.worldbank.org.

\footnotetext{
* Development Economics Research Group, World Bank, 1818 H St, NW, Washington DC, 20433. Email: bsmarzynska@worldbank.org and mspatareanu@worldbank.org. Thanks to Ana Fernandes, Caroline Freund, Holger Görg, Hiau Looi Kee and Kamal Saggi for very useful comments on an earlier draft.
} 


\section{Introduction}

Many countries, including developing and transition economies, offer generous incentive packages to attract foreign direct investment (FDI) justifying their actions with the expected knowledge externalities to be generated by foreign affiliates operating in their economy. While a lot of research effort has been put into looking for the evidence of such externalities, ${ }^{1}$ little attention has been devoted to how the degree of foreign ownership affects knowledge spillovers from FDI. A notable exception is a study by Blomström and Sjöholm (1999) who employ crosssection data on Indonesian firms and find that there is no statistically significant difference between within-industry spillovers associated with minority- and majority-owned foreign projects. They also show that FDI, regardless of the degree of ownership, has a significant positive effect on the productivity of Indonesian firms operating in the same industry. In contrast, Dimelis and Louri (2001), using cross-sectional data on Greek manufacturing firms, demonstrate that while the labor productivity of domestic firms is enhanced by the presence of foreign affiliates in the same industry, spillovers stemming from minority-owned foreign establishments are larger than those from majority-owned ones.

This paper investigates this question in more detail by extending the analysis to: (i) examine the difference between spillovers associated with fully- and partially-owned foreign investments in addition to comparing the impact of majority- and minority-owned foreign projects, and (ii) study both intra- (horizontal) as well as inter-industry (vertical) spillovers stemming from different types of foreign establishments. Moreover, this study significantly improves upon the econometric techniques employed in the earlier literature by controlling for unobserved firm heterogeneity and taking into account the endogeneity of input selection with

\footnotetext{
${ }^{1}$ Most of the existing firm level studies, including Haddad and Harrison (1993) on Morocco, Aitken and Harrison (1999) on Venezuela, Djankov and Hoekman (2000) on the Czech Republic, and Konings (2000) on Bulgaria, Poland and Romania cast doubt on the existence of horizontal (i.e., intra-industry) spillovers from FDI in developing countries. They either fail to find a significant effect or produce the evidence of the negative impact the presence of multinational corporations has on domestic firms in the same sector. The few studies finding evidence of positive within-sector spillovers focus on developed countries (e.g., Haskel, Pereira and Slaughter, 2002, on the UK). The exceptions are Konings (2001) and Kinoshita (2001) who found evidence of positive horizontal spillovers in R\&D intensive sectors in Bulgaria and Poland, and the Czech Republic, respectively. The picture is more optimistic in the case of inter-industry, or vertical spillovers, taking place through contacts between domestic firms and their multinational customers operating in the same country. Blalock (2001), Schoors and van der Tol (2001) and Smarzynska (2002) provide evidence consistent with the presence of positive FDI spillovers operating through this channel.
} 
respect to productivity, which allows for consistent estimates of production function. ${ }^{2}$ These improvements are possible since, unlike the existing literature which relies on cross-sectional information, this study employs a firm level panel dataset.

The ownership structure of FDI may affect the presence of horizontal (or intra-industry) spillovers in two ways. First, as Blomström and Sjöholm (1999) mentions, it is generally believed that participation of local capital in a foreign investment project reveals the multinational's proprietary technology and thus facilitates spillovers. This belief has led many governments in developing countries to introduce restrictions on the degree of foreign ownership allowed in firms operating in their country. ${ }^{3}$ Second, fear of technology leakage, especially in countries with limited rule of law, may induce firms with most sophisticated technologies to shy away from shared ownership and instead choose to invest only in fully-owned subsidiaries. ${ }^{4}$ As demonstrated by Ramacharandran (1993), foreign investors tend to devote more resources to technology transfer to their wholly-owned subsidiaries than to partially-owned affiliates. In the same manner, Mansfield and Romero (1980) point out that the transfer of technology is more rapid within wholly-owned networks of multinationals' subsidiaries than to joint ventures or licensees. Hence, partially-owned investment project may present a smaller potential for spillovers. The overall relationship between the share of foreign ownership and spillovers is a result of these two forces and its sign is, therefore, ambiguous.

Turning to determinants of vertical (or inter-industry) spillovers, it has been argued that affiliates established through joint ventures or mergers and acquisitions are more likely to source their inputs locally than those taking form of greenfield projects (UNCTC 2001). While the latter need to put significant efforts into developing linkages with local suppliers, the former can take advantages of the supplier relationships of the acquired firm or the local partner. Empirical evidence to support this view has been found for Japanese investors (Belderbos et al. 2001) and for Swedish affiliates in Eastern and Central Europe (UNCTC 2000). On the other hand, anecdotal evidence suggests that foreign investors acquiring local firms in transition countries

\footnotetext{
${ }^{2}$ Griliches and Mairesse (1995) have argued that inputs should be considered endogenous since they are chosen by a firm based on its productivity, which is observed by the producer but not by the econometrician. Not taking into account the endogeneity of input choices biases the estimated production function coefficients. Since the focus of this paper is on firm productivity, the consistency of the estimates is crucial for the analysis.

${ }^{3}$ For instance, in the 1980s restrictions on foreign ownership were present in China, India, Indonesia, Malaysia, Mexico, Nigeria, Pakistan, the Republic of Korea and Sri Lanka (UNCTC, 1987).

${ }^{4}$ See Smarzynska and Wei (2000) and Javorcik and Saggi (2002).
} 
tend to dramatically reduce the number of local suppliers. ${ }^{5}$ While in our dataset we cannot distinguish between acquisitions, joint ventures and greenfield projects, we have detailed information on the foreign equity share. To the extent that full foreign ownership is a proxy for greenfield projects and full acquisitions, we expect that fully-owned foreign affiliates will rely more on imported inputs, while investment projects with local capital will source more locally. ${ }^{6}$ Therefore, we anticipate larger spillovers to be associated with partially-owned foreign projects than with fully-owned foreign subsidiaries. This effect may be reinforced by the fact that fullyowned foreign affiliates may use newer or more sophisticated technologies than their partiallyowned counterparts and thus may have higher requirements vis-à-vis suppliers which only a handful of domestic firms, if any, would be able to meet.

We examine the above hypotheses using data from the Amadeus database which includes information on 54,032 Romanian firms for the period 1998-2000. In contrast to the findings of Blomström and Sjöholm (1999), our results suggest that the degree of foreign ownership matters for horizontal spillovers. Moreover, it also affects the degree of vertical spillovers from FDI. When we estimate a regression similar to the cross-sectional one employed by Blomström and Sjöholm we confirm their result of no difference between spillovers associated with minorityand majority-owned foreign projects. However, when we compare the effects of fully- and partially-owned foreign investments we find a significant difference between the two. Only the fully-owned foreign investments are found to be associated with positive productivity spillovers within a sector. We also test for the difference in the effect of minority-owned, majority-but-notfully-owned and fully-owned projects. Interestingly enough, we find that positive spillovers are associated only with fully-owned foreign projects and that there is no statistically significant difference between spillovers stemming from the two other types of FDI.

\footnotetext{
${ }^{5}$ One of the largest FDI projects in Romania, Renault's purchase of an equity stake in Dacia, the local automobile maker, may serve as an example. The initial transaction took place in 1999 with subsequent increases in Renault's share in 2001 and 2002. After the acquisition, the French company promised to continue sourcing inputs from local suppliers provided they lived up to the expectations of the new owner. This, however, does not seem to have been the case. In 2002, eleven foreign suppliers of the French group were expected to start operating in Romania, thus replacing the Romanian producers from whom Dacia used to source (Ziarul Financiar (Financial Newspaper) April $19,2001)$.

${ }^{6}$ A recent survey of multinationals operating in Latvia provides support for this view as it shows that while 52 percent of firms with joint domestic and foreign ownership had at least one local supplier of intermediate inputs, the same was true of only 9 percent of fully-owned foreign subsidiaries. Moreover, partially-owned foreign buyers were reported to offer more technical, managerial and financial assistance to their suppliers than fully-owned ones (FIAS 2003).

Further, the results of a study of the largest exporters in Hungary also indicate that foreign affiliates with larger share of foreign equity tend to purchase fewer inputs from Hungarian companies (Toth and Semjen 1999).
} 
Next we improve upon the Blomström and Sjöholm's methodology by controlling for unobserved firm characteristics and confirm that only the fully-owned foreign projects result in positive horizontal spillovers and that there are no significant effects associated with minority and majority-but-not-fully-owned foreign projects. Again the difference between spillovers associated with fully- and partially-owned foreign projects is statistically significant. Furthermore, we implement the Olley and Pakes (1996) correction for endogeneity of input selection and control for industry concentration and still find that the degree of foreign ownership in investment projects matters for the extent of intra-industry spillovers.

Finally, we find a pattern of vertical spillovers that is consistent with our expectations. Our results suggest that positive externalities are associated with partially-owned foreign projects which were hypothesized to rely more heavily on local suppliers. On the other hand, fullyowned foreign subsidiaries are shown to have a negative effect on productivity of domestic firms in upstream sectors. This negative effect may be due to the fact that foreign investors acquiring domestic enterprises may upgrade production facilities which results in demand for more complex, higher quality inputs and leads to severing existing relationships with local suppliers and greater reliance on imported inputs. The subsequent decrease in demand for intermediates produced in Romania may prevent local producers from reaping the benefits of scale economies. ${ }^{7}$

This paper is structured as follows. In the next section, we discuss FDI inflows into Romania. Then we present our data, estimation strategy and the empirical results. The last section concludes.

\section{FDI in Romania}

After the collapse of the communist regime in 1989, Romania started its transformation to a market economy. During the first years following the regime change, the government took a cautious approach to transition. Privatization in Romania lagged behind those in other Central East European countries and so did FDI inflows. The situation changed after 1997 when a mass-

\footnotetext{
7 This finding is consistent with the case study discussed in the previous footnote and the anecdotal evidence from the Czech Republic indicating that multinationals upgrading or changing the nature of their production may switch from local to global sourcing and thus drop their suppliers in a host country (KPMG 2002). This result is also in line with the theoretical predictions of Saggi (2002) who shows that local suppliers of intermediates will be worse off after the entry of multinationals if the technology gap between local and foreign producers of final goods is large.
} 
privatization program was implemented. The privatization initiative together with the changes in the legislative framework and the incentives given for FDI provided new opportunities for foreign investors. FDI became permitted in virtually all economic sectors, full ownership was allowed and there were no restrictions on profit repatriation. Foreign investors were offered guarantees against nationalization and expropriation as well as tax incentives including exemptions from customs duties, VAT exemptions for imports and tax holidays.

As a result, FDI inflows in Romania, slow in the early 1990s, picked up rapidly after 1996. The amount of FDI received in 1998 was more than 20 times larger than that in 1993. The total volume of foreign direct investment during the period 1991-August 2001 totaled seven billion dollars. The number of companies with foreign capital reached over 80 thousand by mid-August 2001, representing about 9 percent of all companies registered in Romania. In terms of the number of investment projects Italy ranked first, followed by Germany, China and Turkey. Preferred areas for FDI included oil exploration, automobile and automotive component industry, banking and finance, food processing, telecommunications and construction. Romania is the fourth largest FDI recipients among Central and Eastern European countries but ranks tenth in the region in terms of FDI inflows per capita (see Table 1).

\section{Data Description}

The data used in this study come from a commercial database Amadeus compiled by Bureau van Dijk, which contains comprehensive information on companies operating in thirtyfive European countries, including Romania. The Amadeus database covers 387, 357 firms out of 783,969 (308,064 reported active) firms registered in Romania at the end of year $2000 .{ }^{8}$ The difference comes from the fact that while Amadeus includes some inactive companies, it does not cover state owned firms or co-operatives. Information on the firms included in Amadeus comes from the Chamber of Commerce and Industry of Romania. In addition to the standard financial statements, Amadeus includes detailed information about the ownership structure of firms which allows us to determine the foreign equity stake in each company. Unfortunately, the database contains only the latest available ownership information (mostly for 2000 and 1999)

\footnotetext{
${ }^{8}$ Source: Romanian Statistical Yearbook (2001).
} 
and no historical figures. ${ }^{9}$ For this reason, we limit our analysis to an unbalanced panel spanning over the period 1998-2000. We assume that firms which were foreign-owned in the year for which we have the ownership information were foreign-owned during the whole three-year period.

The sample includes firms with more than five employees in 1999. After deleting inactive firms and missing observations and removing outliers, ${ }^{10}$ we are left with 54,032 firms (or 131,396 firm-year observations, between 42,246 and 52,240 observations per year). For 6,262 firms the foreign capital share exceeds ten percent of the total.

We also employ the input-output matrix provided by the Statistical Institute of Romania for the first year covered by the sample 1998. ${ }^{11}$ The input-output matrix contains 105 sectors and each firm in our dataset is matched with the IO sector classification based on its primary three-digit NACE code. The concordances between the IO industry codes and three digits NACE codes are provided in Appendix Table A1. All sectors of the economy are represented in our sample. A detailed sectoral distribution of firms is presented in Table 2. As summary statistics presented in Table 3 indicate, a large degree of heterogeneity is found in the case of outputs, inputs and ownership type.

\section{Empirical Strategy}

\section{Model}

To examine the effect of foreign presence on productivity of domestic firms, we estimate a log-linear transformation of a Cobb-Douglas production function:

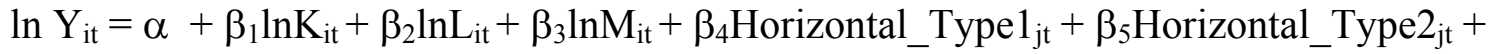

$$
\begin{aligned}
& +\beta_{7} \text { Vertical_Type } 1_{\mathrm{jt}}+\beta_{8} \text { Vertical_Type } 2_{\mathrm{jt}}+\alpha_{\mathrm{t}}+\alpha_{\mathrm{j}}+\varepsilon_{\mathrm{ijt}}
\end{aligned}
$$

\footnotetext{
${ }^{9}$ Despite this shortcoming many researchers studying European economies have employed the Amadeus data. See, for instance, Budd, Konings and Slaughter (2002), Castellani and Zanfei (2001), Konings and Murphy (2001), Konings, Rizov and Vandenbussche (2003), Schoors and van der Tol (2001).

${ }^{10}$ Firms in the top and bottom one percentile of all the firm-specific output and input variables were deleted from the sample.

11 Ideally we would like to use multiple input-output matrices since relationships between sectors may change over the years or with FDI inflows, albeit radical changes are unlikely. Unfortunately, input-output matrices for later years are not available.
} 
where subscripts $i, j$ and $t$ refer to firm, industry and time, respectively. $\mathrm{Y}_{\mathrm{it}}$ stands for firm output. $\mathrm{K}_{\mathrm{it}}, \mathrm{L}_{\mathrm{it}}$ and $\mathrm{M}_{\mathrm{it}}$ represent production inputs: capital, labor, and materials. $\alpha_{\mathrm{t}}$ and $\alpha_{\mathrm{j}}$ capture time and industry effects, respectively. We define output as firm's turnover deflated by industry specific producer price indices at the two-digit NACE classification. We measure labor by the number of employees. Capital is proxied by the value of tangible fixed assets deflated using the GDP deflator. Material inputs are deflated by a weighted average of the producer price indices of the supplying sectors. The weights are given by the input-output matrix and represent the proportion of inputs sourced from a given sector.

In addition to the standard production function variables, we include measures of foreign presence in the same sector (Horizontal) as well as in downstream sectors (Vertical), which are defined as follows. Horizontal ${ }_{\mathrm{jt}}$ is the share of an industry j's output produced by firms with at least ten percent foreign equity, calculated for each of the 105 industries. Even though the number of foreign firms does not change during the sample period, output fluctuates and thus it is a sector-specific time-varying variable. Since we are interested in exploring spillovers stemming from different types of FDI projects, we calculate separately measures of foreign presence pertaining to minority- and majority-owned foreign investments as well as to partiallyand fully-owned foreign projects.

The variable Vertical $_{j t}$ is a proxy for the foreign presence in downstream sectors (i.e., sectors supplied by the industry to which the firm in question belongs) and thus is intended to capture the effect multinational customers have on domestic suppliers. It is defined in the following way:

$$
\text { Vertical }_{\mathrm{jt}}=\Sigma_{\mathrm{k}} \alpha_{\mathrm{jk}} \text { Horizontal }_{\mathrm{kt}}
$$

where $\alpha_{\mathrm{jk}}$ is the proportion of sector $\mathrm{j}$ 's output used by sector k taken from the 1998 input-output matrix including 105 sectors. ${ }^{12}$ We calculate two separate measures of Vertical: one for partiallyand one for fully-owned foreign projects by using the appropriate definition of Horizontal variables defined above. ${ }^{13}$ For summary statistics on these and other variables see Table 3.

\footnotetext{
${ }^{12}$ In calculating $\alpha_{\mathrm{jk}}$ sector j's output sold for final consumption was excluded.

${ }^{13}$ Note that we do not calculate separate measures of Vertical for minority and majority foreign projects, as there is no theoretical argument suggesting that they should be different.
} 


\section{$\underline{\text { Estimation issues }}$}

Blomström and Sjöholm (1999) estimate a version of the above equation on the sample of domestic firms using ordinary least squares correcting the standard errors for heteroskedasticity. We will employ their estimation strategy and restrict our attention to domestic establishments. Considering only domestic firms has two advantages. It allows us to focus on the impact of FDI on domestic firms and avoid a potential bias stemming from the fact that foreign investors tend to acquire stakes in large and most successful domestic companies (see Djankov and Hoekman, 2000). The regressions will include time and industry fixed effects. The results from this specification are presented mainly for comparison purposes as they suffer from two econometric shortcomings.

The first shortcoming of the above empirical strategy is that it does not take into account unobserved firm characteristics, such a managerial talent, availability of better infrastructure or access to financing, etc., which may affect firm productivity. To address this issue we will reestimate our model as a panel with firm fixed effects. It will allow us to control for time invariant determinants of productivity across firms that are also potentially correlated with FDI variables.

The second shortcoming is the fact that the firm's private knowledge of its productivity (unobserved by the econometrician) may affect the input decisions, leading to biased estimates of the coefficients on factor shares. Since our study relies on correctly measuring firm productivity, obtaining consistent estimates of the production function coefficients is crucial to our analysis. Some studies attempt to correct for the simultaneity bias by assuming that the unobserved firm heterogeneity can be captured by a time-invariant fixed effect or by using instrumental variables. However, both approaches rely on the simplifying assumptions of time-invariance of the firmspecific effect in the former case and no serial correlation of the productivity shocks in the latter and are, therefore, not entirely satisfactory.

For this reason, we employ the semi-parametric approach to estimating production function parameters suggested by Olley and Pakes (1996) and modified by Levinsohn and Petrin (2000). This method allows for firm-specific productivity differences that exhibit idiosyncratic changes over time and thus addresses the simultaneity bias. To illustrate the insights of the method, we start with the following production function: 
where va stands for value added (i.e., output minus material inputs), 1 labor, $\mathrm{k}$ capital, and $\mathrm{i}$ and $\mathrm{t}$ are subscripts denoting firm and time, respectively. Capital is treated as a state variable while labor and materials are assumed to be freely variable inputs. $\eta_{\text {it }}$ represents the error term capturing unpredictable shocks, while $\omega_{\mathrm{it}}$ is a productivity shock which is unobserved by the econometrician but known to the firm. Firms adjust their variable inputs based on their anticipation or knowledge of the productivity component $\left(\omega_{\mathrm{it}}\right)$. Since there exists a correlation between the error term $\left(\omega_{\mathrm{it}}+\eta_{\mathrm{it}}\right)$ and the explanatory variables, a simple OLS procedure leads to inconsistent parameter estimates.

As Levinsohn and Petrin (2000) showed, the unobserved productivity can be identified from the firms' observable variable input choices. The chosen variable input is material inputs. ${ }^{14}$ The demand for materials can be modeled as a monotonic function of the capital stock and the unobserved (to the econometrician) productivity shock.

$m_{i t}=f\left(k_{i t}, \omega_{i t}\right)$

The first advantage of using intermediate inputs is that they generally respond to the entire productivity term, while investment may respond only to the 'news' in the unobserved term. Further, intermediate inputs provide a simpler link between the estimation strategy and the economic theory, primarily because they are not typically state variables.

Assuming the function $f($.) is invertible, the unobservable productivity shock can be expressed as a function of observable variables

$\omega_{i t}=h\left(m_{i t}, k_{i t}\right)$

Note that we assume that materials are a variable input whose choice is affected by $\omega_{I t}$ while capital is determined by past values of productivity only.

\footnotetext{
${ }^{14}$ While Olley and Pakes (1996) use investment to model the unobserved productivity shock, we follow Levinsohn and Petrin (2000) approach and use materials as the instrument to correct for simultaneity bias (as was done by Hallward-Driemeier et al., 2001). We do so because of the lack of reliable information on investment expenditures.
} 
Substituting (3) into (2), we get the equation to be estimated in the first stage of the procedure:

$v a_{i t}=\alpha+\beta_{l} * l_{i t}+\beta_{k} * k_{i t}+h\left(m_{i t}, k_{i t}\right)+\eta_{i t}(4)$

Note that the functional form of $h($.$) is not known. Therefore, \beta_{\mathrm{k}}$ cannot be obtained at this stage. We estimate equation (4) using a third order polynomial expansion in capital and materials to approximate the unknown form of $h($.$) . From this stage we obtain the consistent estimate of the$ labor input coefficient as well as the estimate of the third order polynomial in $m_{i t}$ and $k_{i t}$, to which we refer as $\psi_{\text {it }}$

$\psi_{\mathrm{it}}=\beta_{k} * k_{i t}+h\left(m_{i t}, k_{i t}\right)(5)$

Thus, $h\left(m_{i t}, k_{i t}\right)=\psi_{\mathrm{it}}-\beta_{k} * k_{i t}(6)$

We proceed with the second stage where we estimate the effect of capital and materials on output. Let's consider the expectation of $v a_{t+1}-\beta_{1} * 1_{t+1}$ conditional on the information at time $t$. Assuming that $\omega_{\text {it }}$ follows a first order Markov process, one can rewrite $\omega_{i t+1}$ as a function of $\omega_{i t}$, letting $\xi_{\mathrm{it}+1}$ be the innovation in $\omega_{\mathrm{it}+1}$. And $\omega_{\mathrm{it}}$ can be replaced with a function of $\mathrm{h}\left(\mathrm{m}_{\mathrm{it}}, \mathrm{k}_{\mathrm{it}}\right)$. Therefore the equation to be estimated in the second stage becomes:

$v a_{i t+1}-\beta_{l} * l_{i t+1}=c+\beta_{k} * k_{i t+1}+g\left(h_{i t}().\right)+\xi_{i t+1}+\eta_{i t+1}$

Since the functional for of $\mathrm{g}($.$) is not known, we use once more the third order polynomial$ expansion (with all interactions). Since the capital in use in a given period is assumed to be known at the beginning of the period and $\xi_{\mathrm{it}+1}$ is mean independent of all variables known at the beginning of the period, $\xi_{\mathrm{it}+1}$ is mean independent of $\mathrm{k}_{\mathrm{it}+1}$. The consistent coefficient $\beta_{\mathrm{k}}$ can thus be obtained by running non linear least squares on equation (7).

In summary, following Olley and Pakes(1996) and Levinsohn and Petrin (2000) we use a semi-parametric estimator to generate time-varying firm-specific measures of plant productivity that are consistent even in the presence of input shares being influenced by the private 
knowledge of firm's productivity. The above procedure is performed for each sector separately and the obtained measures of productivity are used in the estimation of equation (1). ${ }^{15}$

\section{$\underline{\text { Results }}$}

We begin our analysis by examining the difference between horizontal spillovers associated with minority- and majority-owned foreign establishments. Due to data constraints, we cannot include all the variables employed by Blomström and Sjöholm (1999) but we employ the same empirical strategy (OLS with White's correction of standard errors). The results, presented in the first column of Table 4, point to the presence of positive intra-industry spillovers, which are, however, significant only in the case majority-owned foreign projects. We confirm Blomström and Sjöholm's findings that there is no statistically significant difference in the magnitude of the coefficients associated with the two types of FDI.

Since, as discussed earlier, there are reasons to expect a difference in spillovers stemming from partially- and wholly-owned foreign projects, we also estimate a model including a separate measure of horizontal spillovers associated with these two types of investment. We find that only fully-owned foreign establishments result in positive and significant horizontal spillovers, and unlike in the previous case, this time the difference between the coefficients is statistically significant. This is consistent with the view that multinationals transfer newer technologies and invest more resources in knowledge transfer to their fully-owned affiliates and thus such affiliates represent a greater potential for spillovers. ${ }^{16}$

Next we test whether the previously found positive effects associated with the majorityowned foreign investments are driven by fully-owned foreign subsidiaries. Thus we include three measures of Horizontal: minority (pertaining to firms with 10-50 percent of foreign share), majority-but-not-fully-owned (above 50 but less than 100 percent foreign ownership) and fullyowned (100 percent foreign ownership). Interestingly, we find that in a regression that includes all three measures the only positive and significant effect is associated with fully-owned foreign

\footnotetext{
${ }^{15}$ Since the procedure described above calls for using lagged variables, we employ a longer panel 1996-2000 to obtain productivity estimates but in the subsequent analysis of spillovers the timeframe is restricted to years 19982000.

${ }^{16}$ Additional regressions (not reported here) performed on a combined sample of both domestic and foreign indicate that fully-owned foreign subsidiaries have higher productivity levels than partially-owned foreign projects and domestic firms.
} 
subsidiaries. The test of equality of coefficients reveals no significant difference between the minority and majority-but-not-fully-owned effects but a statistically significant difference between the impact of fully-owned projects and the other two types of FDI.

Finally we focus on vertical spillovers from FDI by adding to our model two measures of foreign presence in downstream sectors. ${ }^{17}$ While their inclusion has no effect on the coefficients of the Horizontal variables, we find that proxies for vertical spillovers exhibit a very different sign pattern. Namely, partially-owned foreign projects appear to be associated with positive vertical spillovers while full foreign ownership results in negative externalities to domestic firms in upstream industries. The two coefficients as well as the difference between them are statistically significant at the one percent level. Their sign pattern is consistent with the hypothesis that foreign investors entering a host country through greenfield projects or full acquisitions are less likely to source their inputs locally than those who invested through joint ventures or partial acquisitions. ${ }^{18}$ This may be due to the fact that the former group faces higher costs of finding local suppliers and that foreign owners tend to reduce the number of existing suppliers in the acquired firms as they integrate the subsidiary in the supplier network of the parent company. ${ }^{19}$

A serious drawback of the empirical strategy employed so far is its inability to account for unobserved firm characteristics that may influence firm productivity, such as managerial talent, quality of available infrastructure, etc. To take them into account we exploit the panel nature of our dataset and estimate a model with firm specific fixed affects. The findings are presented in Table 5. The results pertaining to the impact of minority versus majority, as well as partial and full foreign ownership on productivity of domestic firms remain qualitatively unchanged thus lending support to our hypotheses.

However, in the fixed effects specification we do find a statistically significant difference between horizontal spillovers associated with minority and majority foreign establishments.

\footnotetext{
${ }^{17}$ Note that we include in the regression only the partially- and fully-owned measures of horizontal spillovers since we found no statistically significant difference between the spillover effects of minority and majority-but-not-fullyowned projects.

${ }^{18}$ Greenfield investments accounted for about 50-60 percent of FDI inflows into Romania before 2002 (Voinea 2003), which is the period covered by our sample.

${ }^{19}$ This point was, for instance, mentioned in "FDI-related policies in Hungary 1990-2001", Investment for Development Project, Consumer Unit and Trust Society. Internet address: http://cuts.org/ifd-lm-cr-hun.doc
} 
While the effects associated with minority ownership are insignificant, the spillovers stemming from majority owned are positive and statistically significant. These findings suggest that firm heterogeneity is important and accounting for it leads to more accurate estimates of spillovers effects associated with different degrees of foreign ownership. Nevertheless, when the majority variable is split into majority-but-not-fully-owned and fully-owned, the difference between the minority and majority- but-not -fully-owned becomes insignificant confirming the previous findings.

The final robustness checks are presented in Table 6. We applied the Olley and Pakes (1996) method to estimate firm-specific total factor productivity and then used it as the dependent variable in an OLS estimation with industry fixed effects as well as in a first difference regression. ${ }^{20}$ Moreover, we added the Herfindahl index to the model to control for industry concentration. ${ }^{21}$ This additional control may be important, since as Aitken and Harrison (1999) pointed out, the estimates of spillover effect may capture the net impact of knowledge externalities and the competition effect. The latter effect is present when foreign entry leads to increased competitive pressures which result in a decline of local firms' market shares, increasing their average costs and thus lowering productivity.

The results are broadly consistent with our previous findings. First, we show that the share of foreign ownership matters for both horizontal and vertical spillovers. In all regressions, the difference between spillovers associated with fully- and partially-owned foreign projects is statistically significant. This is true for both inter- and intra-industry effects. Second, as before the empirical evidence is consistent with positive spillovers from fully-owned foreign investments taking place within sectors. The estimated coefficients are significant at the one percent level in all four regressions. There is, however, some change with respect to horizontal spillovers associated with partially foreign-owned projects. While in the earlier regressions and in the OLS regression with the Olley-Pakes correction the coefficients are not statistically significant, the first difference results suggest that such projects have a negative and significant

\footnotetext{
${ }^{20}$ Since the Olley-Pakes correction was applied to each industry separately, we had to discard industries with insufficient number of observations to carry out the procedure. Hence, Table 6 contains regressions based on a smaller number of observations that the previous tables.

${ }^{21}$ The index is defined as the sum of the squared market shares of the four largest producers in a given sector and its value ranges from 0 to 10000 . As pointed out by Nickell (1996), predictions of the theoretical literature on the impact of competition on productivity are ambiguous. In the empirical analysis, however, he finds evidence of competition being positively correlated with a higher rate of productivity growth.
} 
impact on the performance of domestic firms in their sector. This would suggest that in the case of partially foreign-owned projects, the competition effect (which may not be entirely captured by the Herfindahl index) may outweigh knowledge externalities. However, since this effect is not robust to other specifications, we stop short of drawing strong conclusions about it. Third, as in the earlier regressions, the data suggests that there exist significant negative effects associated with the presence of fully foreign-owned projects in downstream sectors. The evidence of a positive correlation between the presence of partially foreign-owned projects in downstream sectors and the productivity of domestic firms in upstream industries is, however, present only in the first difference regression. In sum, the additional robustness checks lend support to our hypothesis that the degree of spillovers vary with the degree of foreign ownership.

\section{Conclusions}

Governments of developing countries often favor joint ventures over fully-owned FDI projects believing that active participation of local firms in foreign investment projects facilitates the absorption of new technologies and know-how. In this paper, we leave aside the issue of whether this perception is true, and instead test if there is a difference in the magnitude of horizontal and vertical spillovers associated with different degrees of foreign ownership. We find evidence consistent with positive horizontal spillovers resulting from fully-owned foreign establishments but not from partially-owned foreign projects. This finding is in line with the literature suggesting that foreign investors tend to put more resources into technology transfer to their wholly-owned projects than into joint ventures.

A different pattern emerges in the case of vertical spillovers. The data indicate that the presence of partially-owned foreign projects is correlated with higher productivity of domestic firms in upstream industries suggesting that domestic suppliers of intermediates may benefit from contacts with multinational customers. The opposite is true, however, in the case of fully-owned foreign establishments which appear to have a negative effect on domestic firms in upstream sectors. The latter finding is consistent with the observation that foreign investors entering a host country through greenfield projects are less likely to rely on local sourcing due to costs associated with finding domestic suppliers. This result is also supported by the anecdotal evidence suggesting that after a full acquisitions of a domestic enterprise, 
multinationals tend to reduce the number of suppliers often severing existing links with domestic firms in upstream sectors and thus lowering demand for domestically produced intermediates.

While this study sheds some light on the factors driving FDI spillovers, certainly more work is needed to improve our understanding of this phenomenon. 


\section{Bibliography}

Aitken, Brian J. and Ann E. Harrison. 1999. "Do Domestic Firms Benefit from Direct Foreign Investment? Evidence from Venezuela," American Economic Review. 89(3): 605-618

Belderbos, Rene, Giovanni Capannelli and Kyoji Fukao. 2001. "Backward vertical linkages of foreign manufacturing affiliates: Evidence from Japanese multinationals," World Development, 29(1): 189-208.

Blomström, Magnus and Fredrik Sjöholm. 1999. "Technology transfer and spillovers: Does local participation with multinationals matter?” European Economic Review. 43:915-923.

Budd, John, Josef Konings and Matthew J. Slaughter. 2002. "International Rent Sharing in Multinational Firms," NBER Working Paper No. 8809.

Castellani, Davide and Antonello Zanfei, 2001. "Productivity Gaps, Inward Investments and Productivity of European Firms" 0107001, Economics Working Paper Archive at WUSTL.

Dimelis, Sophia and Helen Louri, 2001. "Foreign Direct Investment and Efficiency Benefits: A Conditional Quantile Analysis”, CEPR Working Papers, No. 2868

Djankov, Simeon and Bernard Hoekman. 2000. "Foreign Investment and Productivity Growth in Czech Enterprises," World Bank Economic Review, 14(1): 49-64.

Factbook 2001. The CIA World Factbook. http://www.factbook.net/Sitemap.htm

FIAS, 2003. "Developing Knowledge Intensive Sectors, Technology Transfers, and the Role of FDI." Mimeo, Foreign Investment Advisory Services, the World Bank, Washington, D.C.

Griliches, Z. and J. Mairesse. 1995. "Production Functions: the Search for Identification,” NBER Working Paper 5067.

Haddad, Mona and Ann Harrison. 1993. "Are There Positive Spillovers from Direct Foreign Investment" Evidence from Panel Data for Morocco." Journal of Development Economics. 42(1): 51-74.

Hallward-Driemeier, Mary, Giuseppe Iarossi and Kenneth L. Sokoloff. 2002. "Exports and Manufacturing Productivity in East Asia: A Comparative Analysis with Firm-Level Data," NBER Working Paper No 8894.

Haskel, Jonathan E., Sonia C. Pereira and Matthew J. Slaughter. 2002. "Does Inward Foreign Direct Investment Boost the Productivity of Domestic Firms?" NBER Working Paper 8724.

Javorcik Beata Smarzynska and Kamal Saggi. 2002. "Technological Asymmetry and the Mode of Foreign Investment," Mimeo, the World Bank, Washington, D.C.

Kinoshita, Y. 2000. "R\&D and Technology Spillovers via FDI: Innovation and Absorbtive Capacity", CEPR Discussion Paper 2775

Konings, Jozef and A. Murphy. 2001. "Do Multinational Enterprises Substitute Parent Jobs for Foreign Ones? Evidence from European Firm-Level Panel Data", CEPR Discussion Paper 2972 
Konings, Jozef, , Marian Rizov and Hylke Vandenbussche, 2003. "Investment and Financial Constraints in Transition Economies: Micro Evidence from Poland, the Czech Republic, Bulgaria and Romania”, Economics Letters, Volume 78, Issue 2, February 2003, Pages 253-258

KPMG. 2002. “Impact Assessment of Supplier Development Programme.” Mimeo, CzechInvest, Prague, Czech Republic.

Mansfield, Edwin, and Anthony Romero. 1980. Technology Transfer to Overseas Subsidiaries by US-Based Firms," Quarterly Journal of Economics 95(4), pp.737-750

Nickell, Stephen. 1996. "Competition and Corporate Performance," Journal of Political Economy. 104(4):724-46.

Ramachandaram, Vijaya. 1993. “Technology transfer, Firm Ownership, and Investment in Human Capital," Review of Economics and Statistics 75(4), pp. 664-670

Robinson, P. 1988. "Root-N consistent Semi-parametric Regression”, Econometrica 55, pp. 931954

Saggi, Kamal. 2002. "Backward Linkages under Foreign Direct Investment," mimeo, Southern Methodist University.

Schoors, Koen and Bartoldus van der Tol. 2001. "The productivity effect of foreign ownership on domestic firms in Hungary," mimeo, University of Gent.

Smarzynska, Beata. 2002. "Does Foreign Direct Investment Increase the Productivity of Domestic Firms? In Search of Spillovers through Backward Linkages” World Bank Policy Research Working Paper No. 2923.

Smarzynska, Beata and Shang-Jin Wei. 2000. "Corruption and Composition of Foreign Direct Investment: Firm Level Evidence from Transition Economies” NBER Working Paper No. 7969.

Toth, Ilda. 2000. “Acquisitions in Hungary: Marriages not for love,” HGV, Budapest, 22, 44 (4 November), pp. 78-85.

UNCTC. 1987. Arrangements between Joint Venture Partners in Developing Countries. Advisory Study No. 2. New York: UN.

UNCTC. 2000. World Investment Report. Cross-Border Mergers and Acquisitions and Development.

UNCTC. 2001. World Investment Report. Promoting Linkages.

Voinea, Liviu. 2003. “FDI in Romania Matures,” UNDP Project Early Warning System $\mathrm{ROM} / 99 / 006$. 
Table 1. FDI Inflows into CEEC-10 1993-2000

\begin{tabular}{|c|c|c|c|c|c|c|c|c|c|c|c|c|}
\hline & \multicolumn{8}{|c|}{ FDI inflow (millions of US\$) } & \multicolumn{2}{|c|}{$\begin{array}{c}\text { FDI inflows } \\
2000\end{array}$} & \multicolumn{2}{|c|}{$\begin{array}{c}\text { FDI inflows } \\
1993-2000\end{array}$} \\
\hline & 1993 & 1994 & 1995 & 1996 & 1997 & 1998 & 1999 & 2000 & $\begin{array}{c}\text { as } \% \text { of } \\
\text { GDP }\end{array}$ & $\begin{array}{c}\text { per } \\
\text { capita }\end{array}$ & $\begin{array}{c}\begin{array}{c}\text { Value } \\
\text { (mn US\$) }\end{array} \\
\end{array}$ & $\begin{array}{l}\text { Per capita } \\
\text { (US\$) }\end{array}$ \\
\hline Poland & 1,715 & 1,875 & 3,659 & 4,498 & 4,908 & 6,365 & 7,270 & 9,342 & 5.9 & 242 & 39,632 & 1,025 \\
\hline Czech Republic & 654 & 878 & 2,568 & 1,435 & 1,286 & 3,700 & 6,313 & 4,583 & 9.3 & 446 & 21,417 & 2,085 \\
\hline Hungary & 2,350 & 1,144 & 4,519 & 2,274 & 2,167 & 2,037 & 1,977 & 1,692 & 3.7 & 169 & 18,159 & 1,812 \\
\hline Romania & 94 & 341 & 419 & 263 & 1,215 & 2,031 & 1,041 & 1,025 & 2.8 & 46 & 6,429 & 287 \\
\hline Slovak Republic & 199 & 270 & 236 & 351 & 174 & 562 & 354 & 2,052 & 10.7 & 380 & 4,198 & 777 \\
\hline Bulgaria & 40 & 105 & 90 & 109 & 505 & 537 & 806 & 1,002 & 8.3 & 123 & 3,194 & 391 \\
\hline Latvia & 45 & 214 & 180 & 382 & 521 & 357 & 348 & 407 & 5.7 & 169 & 2,454 & 1,015 \\
\hline Lithuania & 30 & 31 & 73 & 152 & 355 & 926 & 486 & 379 & 3.4 & 102 & 2,432 & 658 \\
\hline Estonia & 162 & 214 & 201 & 150 & 266 & 581 & 305 & 387 & 7.8 & 270 & 2,268 & 1,580 \\
\hline Slovenia & 113 & 128 & 177 & 194 & 375 & 248 & 181 & 181 & 1.0 & 91 & 1,597 & 803 \\
\hline
\end{tabular}

Source: IMF International Financial Statistics (FDI figures) and World Bank World Development Indicators (GDP and population) 
Table 2. Distribution of Firms With Foreign Capital By Industry

\begin{tabular}{|c|c|c|c|c|c|}
\hline \multirow[t]{2}{*}{ Industry code } & \multirow{2}{*}{$\begin{array}{c}\begin{array}{c}\text { Domestic } \\
\text { Firms }\end{array} \\
<10 \% \\
\end{array}$} & \multicolumn{3}{|c|}{ Firms with Foreign Capital } & \multirow[t]{2}{*}{ Total } \\
\hline & & $10<=\mathrm{FO}<50$ & $50<=\mathrm{FO}<100$ & $\mathrm{FO}=100$ & \\
\hline 1 & 798 & 12 & 30 & 21 & 861 \\
\hline 3 & 94 & 2 & 2 & 1 & 99 \\
\hline 6 & 26 & 0 & 0 & 0 & 26 \\
\hline 8 & 543 & 10 & 27 & 26 & 606 \\
\hline 9 & 37 & 1 & 5 & 1 & 44 \\
\hline 13 & 673 & 7 & 11 & 5 & 696 \\
\hline 14 & 44 & 2 & 3 & 2 & 51 \\
\hline 15 & 14 & 1 & 1 & 0 & 16 \\
\hline 16 & 82 & 0 & 3 & 1 & 86 \\
\hline 18 & 646 & 20 & 28 & 26 & 720 \\
\hline 19 & 27 & 0 & 0 & 2 & 29 \\
\hline 20 & 134 & 4 & 10 & 11 & 159 \\
\hline 21 & 62 & 0 & 7 & 5 & 74 \\
\hline 22 & 298 & 9 & 11 & 7 & 325 \\
\hline 23 & 461 & 18 & 21 & 21 & 521 \\
\hline 24 & 18 & 1 & 2 & 3 & 24 \\
\hline 25 & 2164 & 49 & 150 & 116 & 2479 \\
\hline 26 & 343 & 17 & 27 & 23 & 410 \\
\hline 28 & 1807 & 45 & 139 & 213 & 2204 \\
\hline 29 & 87 & 4 & 3 & 7 & 101 \\
\hline 30 & 30 & 1 & 2 & 0 & 33 \\
\hline 31 & 379 & 6 & 50 & 90 & 525 \\
\hline 32 & 1183 & 31 & 104 & 91 & 1409 \\
\hline 33 & 138 & 12 & 25 & 13 & 188 \\
\hline 34 & 1010 & 46 & 68 & 45 & 1169 \\
\hline 36 & 7 & 0 & 1 & 3 & 11 \\
\hline 38 & 74 & 6 & 10 & 9 & 99 \\
\hline 40 & 59 & 3 & 7 & 3 & 72 \\
\hline 41 & 90 & 6 & 4 & 5 & 105 \\
\hline 42 & 54 & 3 & 8 & 17 & 82 \\
\hline 43 & 63 & 2 & 3 & 3 & 71 \\
\hline 44 & 3 & 1 & 0 & 0 & 4 \\
\hline 45 & 112 & 5 & 6 & 8 & 131 \\
\hline 46 & 274 & 21 & 34 & 40 & 369 \\
\hline 47 & 110 & 4 & 11 & 6 & 131 \\
\hline 48 & 57 & 3 & 5 & 5 & 70 \\
\hline 49 & 8 & 0 & 0 & 0 & 8 \\
\hline 50 & 90 & 0 & 8 & 5 & 103 \\
\hline 51 & 11 & 0 & 1 & 1 & 13 \\
\hline 52 & 98 & 5 & 4 & 4 & 111 \\
\hline 53 & 52 & 0 & 5 & 1 & 58 \\
\hline 54 & 14 & 0 & 5 & 2 & 21 \\
\hline
\end{tabular}




\begin{tabular}{|c|c|c|c|c|c|}
\hline 55 & 13 & 0 & 2 & 5 & 20 \\
\hline 56 & 9 & 0 & 2 & 1 & 12 \\
\hline 57 & 9 & 1 & 1 & 1 & 12 \\
\hline 58 & 20 & 1 & 7 & 3 & 31 \\
\hline 59 & 65 & 1 & 3 & 5 & 74 \\
\hline 60 & 1014 & 24 & 49 & 53 & 1140 \\
\hline 61 & 41 & 2 & 7 & 3 & 53 \\
\hline 62 & 78 & 5 & 9 & 5 & 97 \\
\hline 63 & 21 & 0 & 6 & 1 & 28 \\
\hline 64 & 41 & 1 & 6 & 6 & 54 \\
\hline 65 & 67 & 1 & 12 & 7 & 87 \\
\hline 67 & 37 & 4 & 4 & 5 & 50 \\
\hline 68 & 98 & 8 & 13 & 15 & 134 \\
\hline 69 & 141 & 6 & 15 & 18 & 180 \\
\hline 70 & 54 & 11 & 6 & 10 & 81 \\
\hline 71 & 109 & 6 & 11 & 11 & 137 \\
\hline 72 & 89 & 5 & 8 & 4 & 106 \\
\hline 73 & 69 & 1 & 4 & 2 & 76 \\
\hline 74 & 17 & 0 & 1 & 0 & 18 \\
\hline 77 & 551 & 18 & 49 & 40 & 658 \\
\hline 78 & 191 & 3 & 19 & 21 & 234 \\
\hline 79 & 18 & 0 & 2 & 0 & 20 \\
\hline 80 & 4 & 0 & 3 & 1 & 8 \\
\hline 81 & 43 & 1 & 1 & 1 & 46 \\
\hline 82 & 71 & 0 & 0 & 0 & 71 \\
\hline 83 & 4193 & 60 & 86 & 54 & 4393 \\
\hline 84 & 19900 & 385 & 904 & 887 & 22076 \\
\hline 85 & 321 & 8 & 20 & 13 & 362 \\
\hline 86 & 2065 & 26 & 73 & 46 & 2210 \\
\hline 87 & 8 & 1 & 2 & 2 & 13 \\
\hline 88 & 1528 & 40 & 111 & 117 & 1796 \\
\hline 90 & 30 & 1 & 4 & 2 & 37 \\
\hline 91 & 9 & 1 & 0 & 1 & 11 \\
\hline 92 & 113 & 7 & 8 & 13 & 141 \\
\hline 93 & 275 & 9 & 24 & 28 & 336 \\
\hline 95 & 234 & 11 & 16 & 17 & 278 \\
\hline 97 & 214 & 7 & 19 & 11 & 251 \\
\hline 98 & 376 & 20 & 49 & 54 & 499 \\
\hline 99 & 78 & 2 & 2 & 4 & 86 \\
\hline 100 & 541 & 18 & 30 & 16 & 605 \\
\hline 101 & 1150 & 38 & 91 & 100 & 1379 \\
\hline 102 & 13 & 0 & 1 & 0 & 14 \\
\hline 103 & 142 & 3 & 1 & 4 & 150 \\
\hline 104 & 208 & 3 & 21 & 10 & 242 \\
\hline 105 & 1228 & 26 & 100 & 58 & 1412 \\
\hline Total & 47770 & 1122 & 2643 & 2497 & 54032 \\
\hline
\end{tabular}


Table 3. Summary Statistics

\begin{tabular}{lccccc}
\hline \multicolumn{1}{c}{ Variable } & Nr. Obs & Mean & Std. Dev. & Min & Max \\
\hline & & & & & \\
Sales (th. Lei 1995) & 131,396 & $7,113.6$ & $11,498.8$ & 17.8 & $208,280.0$ \\
Fixed assets (th. Lei 1995) & 131,396 & $1,399.9$ & $3,757.3$ & 0.004 & $56,666.2$ \\
Materials (th. Lei 1995) & 131,396 & $5,265.0$ & $9,042.1$ & 8.4 & $102,814.1$ \\
Number of Employees & 131,396 & 20.4 & 37.1 & 2.0 & 410.0 \\
& & & & & \\
Horizontal minority & 131,396 & 0.033 & 0.02 & 0 & 0.29 \\
Horizontal majority & 131,396 & 0.146 & 0.07 & 0 & 0.88 \\
Horizontal partially-owned & 131,396 & 0.107 & 0.04 & 0 & 0.81 \\
Horizontal majority- but not fully-owned & 131,396 & 0.740 & 0.03 & 0 & 0.80 \\
Horizontal fully-owned & 131,396 & 0.072 & 0.05 & 0 & 0.67 \\
& & & & & \\
Vertical partially-owned & 131,396 & 0.062 & 0.04 & 0 & 0.70 \\
Vertical fully-owned & 131,396 & 0.040 & 0.02 & 0 & 0.21 \\
& & & & & \\
Concentration measure & 131,396 & 28.035 & 154.506 & 0.009 & 5643.91 \\
\hline
\end{tabular}


Table 4. OLS Regressions Results

\begin{tabular}{|c|c|c|c|c|}
\hline & OLS & OLS & OLS & OLS \\
\hline Horizontal minority foreign owned $[10,50]$ & $\begin{array}{l}-0.0312 \\
(0.1876)\end{array}$ & & $\begin{array}{l}-0.0146 \\
(0.1882)\end{array}$ & \\
\hline Horizontal majority foreign owned $(50,100]$ & $\begin{array}{c}0.2924 * * * \\
(0.0869)\end{array}$ & & & \\
\hline Horizontal partially-owned $[10,100)$ & & $\begin{array}{c}0.0341 \\
(0.1002)\end{array}$ & & $\begin{array}{c}0.0719 \\
(0.1008)\end{array}$ \\
\hline Horizontal majority (excluding fully owned) $(50,100)$ & & & $\begin{array}{c}0.0577 \\
(0.1268)\end{array}$ & \\
\hline Horizontal fully-owned [100] & & $\begin{array}{c}0.4442 * * * \\
(0.1083)\end{array}$ & $\begin{array}{c}0.4436 * * * \\
(0.1082)\end{array}$ & $\begin{array}{c}0.4666 * * * \\
(0.1092)\end{array}$ \\
\hline Vertical partially-owned & & & & $\begin{array}{c}0.5272 * * * \\
(0.1360)\end{array}$ \\
\hline Vertical fully-owned & & & & $\begin{array}{c}-1.2670 * * * \\
(0.1796)\end{array}$ \\
\hline Ln fixed assets & $\begin{array}{c}0.0633^{* * *} \\
(0.0011)\end{array}$ & $\begin{array}{c}0.0633^{* * *} \\
(0.0011)\end{array}$ & $\begin{array}{c}0.0633 * * * \\
(0.0011)\end{array}$ & $\begin{array}{c}0.0633 * * * \\
(0.0011)\end{array}$ \\
\hline Ln materials & $\begin{array}{c}0.7102 * * * \\
(0.0017)\end{array}$ & $\begin{array}{c}0.7102 * * * \\
(0.0017)\end{array}$ & $\begin{array}{c}0.7102 * * * \\
(0.0017)\end{array}$ & $\begin{array}{c}0.7104 * * * \\
(0.0017)\end{array}$ \\
\hline Ln labor & $\begin{array}{c}0.2436^{* * *} \\
(0.0024)\end{array}$ & $\begin{array}{c}0.2436^{* * *} \\
(0.0024)\end{array}$ & $\begin{array}{c}0.2436 * * * \\
(0.0024)\end{array}$ & $\begin{array}{c}0.2433^{* * *} \\
(0.0024)\end{array}$ \\
\hline Constant & $\begin{array}{c}1.4789^{* * *} \\
(0.0158)\end{array}$ & $\begin{array}{c}1.4873 * * * \\
(0.0160)\end{array}$ & $\begin{array}{c}1.4871 * * * \\
(0.016)\end{array}$ & $\begin{array}{c}1.5173 * * * \\
(0.0223)\end{array}$ \\
\hline Year dummies & Yes & Yes & Yes & Yes \\
\hline Industry dummies & Yes & Yes & Yes & Yes \\
\hline Adj. R squared & 0.89 & 0.89 & 0.89 & 0.89 \\
\hline No. of observations & 131,396 & 131,396 & 131,396 & 131,396 \\
\hline F test for equal coefficients on Horizontal & 2.39 & 0.71 & 0.09 & 8.07 \\
\hline Prob. $>$ F test Horizontal & 0.123 & 0.003 & $\begin{array}{c}0.76 \\
\text { (min vs. maj) }\end{array}$ & 0.0045 \\
\hline F test for equal coefficients on Horizontal & & & 6.05 & \\
\hline Prob. $>$ F test Horizontal & & & $\begin{array}{c}\mathbf{0 . 0 1 4} \\
\text { (maj vs fully) }\end{array}$ & \\
\hline F test for equal coefficients on Vertical & & & & 79.7 \\
\hline Prob. $>$ F test Vertical & & & & 0.000 \\
\hline
\end{tabular}


Table 5. Fixed Effects Regressions Results

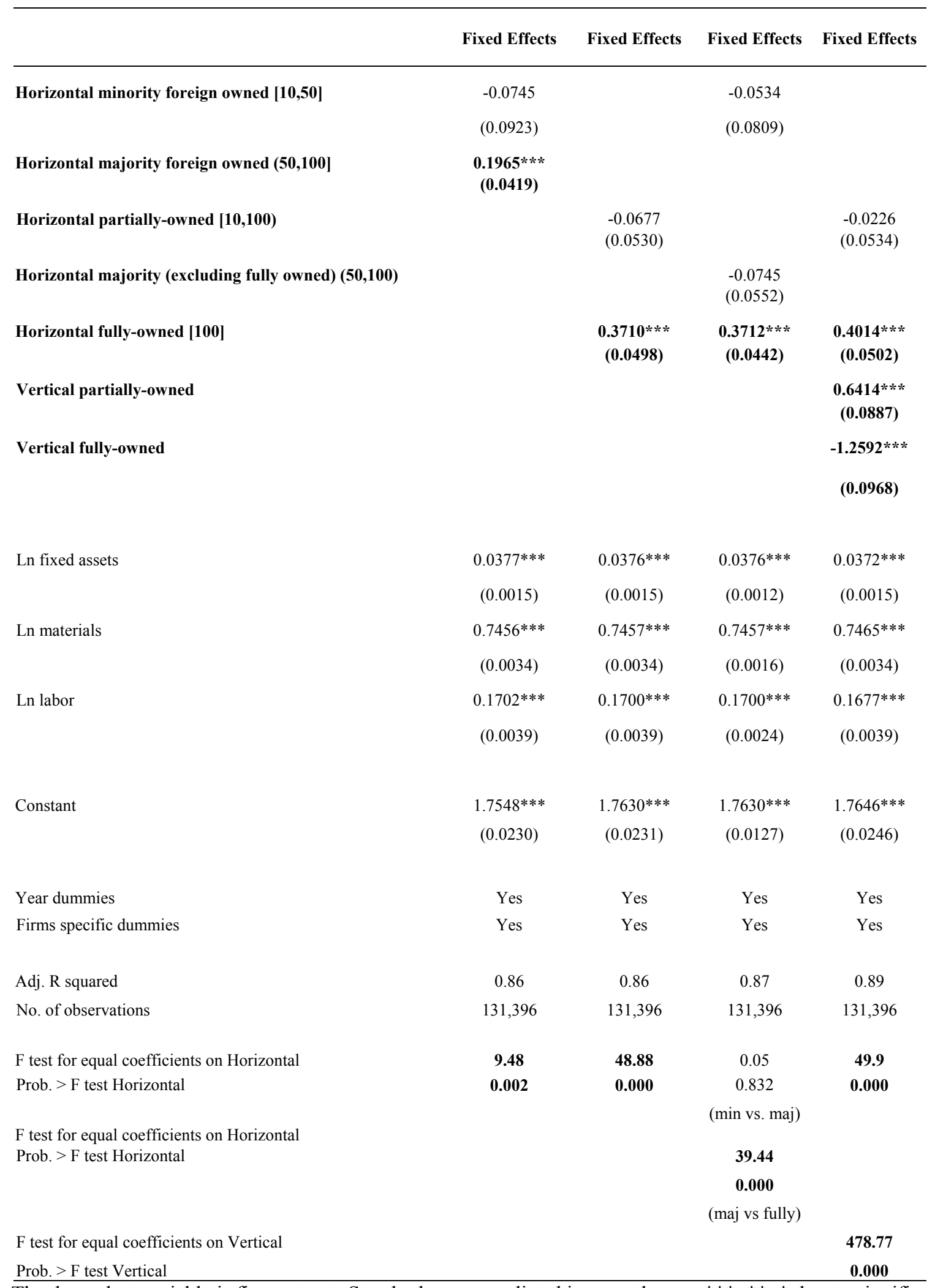

The dependent variable is firm output. Standard errors are listed in parentheses. $* * *, * *, *$ denote significance at the one, five and ten percent level, respectively. 
Table 6 : Olley and Pakes Regressions Results

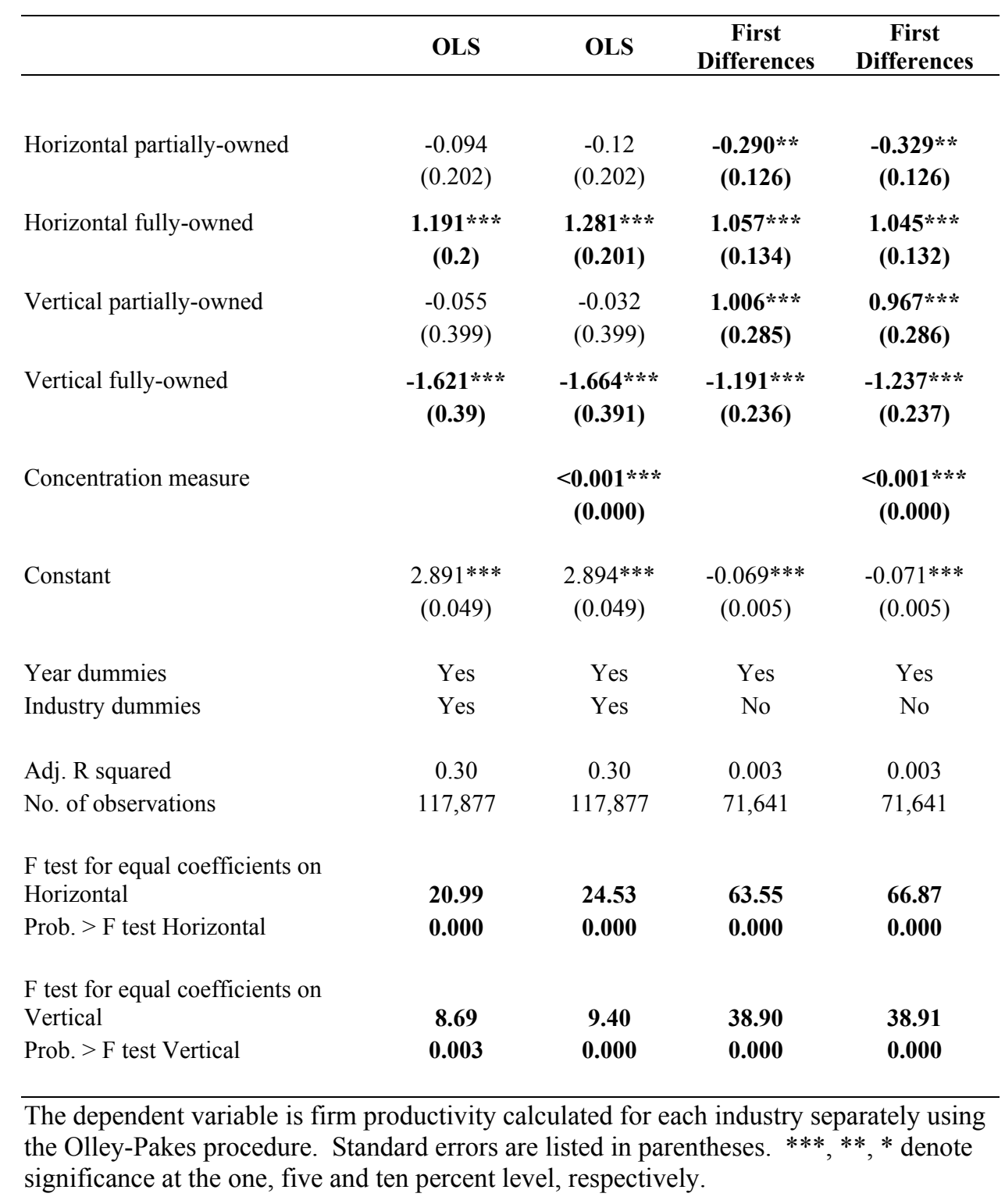




\section{Appendix}

Table 1A. Concordances Table

\begin{tabular}{|c|c|c|}
\hline IO codes & Industry name & NACE \\
\hline 1 & Vegetable production & $01.1 ; 01.3$ \\
\hline 2 & Animal breeding & $01.2 ; 01.3$ \\
\hline 3 & Auxiliary services & 1.4 \\
\hline 4 & Forestry and hunting & $02.0 ; 01.5$ \\
\hline 5 & Logging & 2 \\
\hline 6 & Fishing and aquaculture & 5 \\
\hline 7 & Coal mining and processing & 10 \\
\hline 8 & Extraction of petroleum (including auxiliary services) & $11.1 ; 11.2$ \\
\hline 9 & Extraction of natural gas (including auxiliary services) & $11.1 ; 11.2$ \\
\hline 10 & Radioactive ores quarrying and processing & 12 \\
\hline 11 & Ferrous ores quarrying and processing & 13.1 \\
\hline 12 & Non-ferrous ores quarrying and processing & 13.2 \\
\hline 13 & Extraction of building material ores & 14.1 \\
\hline 14 & Extraction of clay and sand & 14.2 \\
\hline 15 & Extraction and processing of chemical ores & 14.3 \\
\hline 16 & Extraction and processing of salt & 14.4 \\
\hline 17 & Other non-ferrous ores quarrying and processing & 14.5 \\
\hline 18 & Meat production and processing & 15.1 \\
\hline 19 & Processing and preserving of fish and fish products & 15.2 \\
\hline 20 & Processing and preserving of fruits and vegetables & 15.3 \\
\hline 21 & Production of vegetable and animal oil and fat & 15.4 \\
\hline 22 & Production of milk products & 15.5 \\
\hline 23 & Production of milling products, starch and starch products & 15.6 \\
\hline 24 & Manufacture of fodder & 15.7 \\
\hline 25 & Processing of other food products & 15.8 \\
\hline 26 & Beverages & 15.9 \\
\hline 27 & Tobacco products & 16 \\
\hline 28 & Textile industry & 17 \\
\hline 29 & Apparel and clothing & $18.1 ; 18.2$ \\
\hline 30 & Manufacture of leather and fur clothes & 18.3 \\
\hline 31 & Footwear and other leather goods & 19 \\
\hline 32 & Wood processing (excluding furniture) & 20 \\
\hline 33 & Pulp, paper and cardboard; related items & 21 \\
\hline 34 & Publishing, printing and reproduction of recorded media & 22 \\
\hline 35 & Coking & 23.1 \\
\hline 36 & Crude oil processing & 23.2 \\
\hline 37 & Processing of nuclear combustibles & 23.3 \\
\hline 38 & Basic chemical products & 24.1 \\
\hline 39 & Pesticides and other agrochemical products & 24.2 \\
\hline 40 & Dyes and varnishes & 24.3 \\
\hline 41 & Medicines and pharmaceutical products & 24.4 \\
\hline 42 & Soaps, detergents, cosmetics, perfumery & 24.5 \\
\hline
\end{tabular}




\begin{tabular}{|c|c|c|}
\hline 43 & Other chemical products & 24.6 \\
\hline 44 & Synthetic and man made fibres & 24.7 \\
\hline 45 & Rubber processing & 25.1 \\
\hline 46 & Plastic processing & 25.2 \\
\hline 47 & Glass and glassware & 26.1 \\
\hline 48 & Processing of refractory ceramics (excluding building items) & 26.2 \\
\hline 49 & Ceramic boards & 26.3 \\
\hline 50 & Brick, tile and other building material processing & 26.4 \\
\hline 51 & Cement, lime and plaster & 26.5 \\
\hline 52 & Processing of concrete, cement and lime items & 26.6 \\
\hline 53 & Cutting, shaping and finishing of stone & 26.7 \\
\hline 54 & Other non-metallic mineral products & 26.8 \\
\hline 55 & Metallurgy and ferroalloys processing & 27.1 \\
\hline 56 & Manufacture of tubes & 27.2 \\
\hline 57 & Other metallurgy products & 27.3 \\
\hline 58 & Precious metals and other non-ferrous metals & 27.4 \\
\hline 59 & Foundry & 27.5 \\
\hline 60 & Metal structures and products & 28 \\
\hline 61 & $\begin{array}{l}\text { Manufacture of equipment for producing and using of } \\
\text { mechanical power (except for plane engines, vehicles and } \\
\text { motorcycles) }\end{array}$ & 29.1 \\
\hline 62 & Machinery for general use & 29.2 \\
\hline 63 & Agricultural and forestry machinery & 29.3 \\
\hline 64 & Machine tools & 29.4 \\
\hline 65 & Other machines for special use & 29.5 \\
\hline 66 & Armament and ammunition & 29.6 \\
\hline 67 & Labor-saving devices and domestic machinery & 29.7 \\
\hline 68 & Computers and office machinery & 30 \\
\hline 69 & Electric machinery and appliances & 31 \\
\hline 70 & Radio, TV-sets and communication equipment & 32 \\
\hline 71 & Medical, precision, optical instruments and apparatus & 33 \\
\hline 72 & Means of road transport & 34 \\
\hline 73 & Naval engineering and repair & 35.1 \\
\hline 74 & Production and repair of railway transport means & 35.2 \\
\hline 75 & Aircraft engineering and repair & 35.3 \\
\hline 76 & Motorcycles, bicycles and other transport means & $35.4 ; 35.5$ \\
\hline 77 & Furniture & 36.1 \\
\hline 78 & Other industrial activities & $36.2-36.6$ \\
\hline 79 & Electric power production and distribution & 40.1 \\
\hline 80 & Gas production and distribution & 40.2 \\
\hline 81 & Production and distribution of thermal energy & 40.3 \\
\hline 82 & Water collection, treatment and distribution & 41 \\
\hline 83 & Construction & 45 \\
\hline 84 & Wholesale and retail & $50-52$ \\
\hline 85 & Hotels & $55.1 ; 55.2$ \\
\hline 86 & Restaurants & $55.3-55.5$ \\
\hline 87 & Railway transport & 60.1 \\
\hline 88 & Road transport & 60.2 \\
\hline
\end{tabular}




\begin{tabular}{lll}
$\mathbf{8 9}$ & Pipe-line transport & $\mathbf{6 0 . 3}$ \\
$\mathbf{9 0}$ & Water transport & $\mathbf{6 1}$ \\
$\mathbf{9 1}$ & Air transport & $\mathbf{6 2}$ \\
$\mathbf{9 2}$ & Auxiliary transport activities and travel agencies & $\mathbf{6 3 . 1} ; \mathbf{6 3 . 2}$ \\
$\mathbf{9 3}$ & Tourism agencies and assistance & $\mathbf{6 3 . 3}$ \\
$\mathbf{9 4}$ & Post and mail & $\mathbf{6 4 . 1}$ \\
$\mathbf{9 5}$ & Telecommunication & $\mathbf{6 4 . 2}$ \\
$\mathbf{9 6}$ & Financial, banking and insurance services & $\mathbf{6 5}-\mathbf{6 7}$ \\
$\mathbf{9 7}$ & Real estate activities & $\mathbf{7 0}$ \\
$\mathbf{9 8}$ & Computer and related activities & $\mathbf{7 2}$ \\
$\mathbf{9 9}$ & Research and development & $\mathbf{7 3}$ \\
$\mathbf{1 0 0}$ & Architecture, engineering and other technical services & $\mathbf{7 4 . 2}$ \\
$\mathbf{1 0 1}$ & Other business activities & $\mathbf{7 1} ; \mathbf{7 4 . 1} ; \mathbf{7 4 . 3}-$ \\
$\mathbf{1 0 2}$ & Public administration and defense, social assistance & $\mathbf{7 4 . 8}$ \\
$\mathbf{1 0 3}$ & Education & $\mathbf{7 5}$ \\
$\mathbf{1 0 4}$ & Health and social work & $\mathbf{8 0}$ \\
$\mathbf{1 0 5}$ & Other services (collective, social and personal services) & $\mathbf{9 0}-\mathbf{9 9}$ \\
\hline
\end{tabular}

